\title{
Prototype Social Distancing Reminder Using HC-SR04 Sensor At The Payment Counter Via a Smartphone
}

\section{Prototype Pengingat Social Distancing Menggunakan Sensor HC-SR04 Pada Antrian Loket Pembayaran Via Smartphone}

\author{
Ferry Wahyu Perdana ${ }^{1}$, Shazana Dhiya Ayuni ${ }^{2}$, Arief Wisaksono ${ }^{3}$, Syamsudduha Syahrorini $^{4}$ \\ \{fperdana898@gmail.com¹, shazana@umsida.ac.id², ariefwisaksono@umsida.ac.id ${ }^{3}$, syahrorini@umsida.ac.id ${ }^{4}$ \}
}

Program Studi Teknik Elektro, Fakultas Sains dan Teknologi, Universitas Muhammadiyah Sidoarjo

\begin{abstract}
Starting from the beginning of March 2019 and even until the end of 2020, the Indonesian people are experienced prolonged suffering due to the emergence of a new type of infectious disease called Corona Virus 2019. Social Distancing is a program that aims to prevent the transmission of the COVID-19 disease as early as possible. In this research, the method used is the observation technique and literature study for the implementation of the HCSRO4 sensor as one of the distance sensors used for distance reminders implemented in public spaces using IoT as a monitoring system. The results obtained are the reading accuracy of the HC-SR04 sensor is quite accurate to 100\% accuracy and when the HC-SRO4 sensor detects less than $8 \mathrm{~cm}$ (1meter real distance) then the DF Player will sound, the LCD will display a display "Jaga Jarak Anda!", And there will be a notification"Peringatan: Kondisikan Jarak" on a smartphone that has the Blynk application installed.
\end{abstract}

Keywords - IoT; Sensor HC-SRO4 ;Social Distancing

\begin{abstract}
Abstrak. Terhitung mulai awal maret 2019 bahkan sampai dengan akhir 2020, masyarakat Indonesia mengalami penderitaan yang berkepanjangan disebabkan oleh kemunculan satu jenis penyakit menular baru yang disebut dengan Corona Virus 2019. Social Distancing merupakan salah satu program yang memiliki tujuan guna pencegahan secara sedini mungkin untuk penularan penyakit COVID-19. Pada penelitian kali ini metode yang di gunakan ialah teknik observasi dan studi pustaka untuk pengimplementasian sensor HC-SRO4 sebagai salah satu sensor jarak yang digunakan untuk pengingat jarak yang di implementasikan pada ruang publik dengan menggunakan IoT sebagai sistem monitoringnya. Adapun hasil yang di dapatkan ialah akurasi pembacan dari sensor HC-SR04 cukup akurat hingga tingkat keakurasiannya 100\% dan ketika sensor HC-SR04 mendeteksi kurang dari 8cm (1meter jarak nyata) maka DF Player akan berbunyi, LCD akan menampilkan display "jaga jarak anda!", serta akan terdapat notifikasi "Peringatan : Kondisikan Jarak" pada smartphone yang telah terpasang aplikasi blynk.
\end{abstract}

Kata Kunci - IoT; Sensor HC-SRO4 ;Social Distancing

\section{Pendahuluan}

Pada awal maret 2020 bahkan hingga akhir tahun 2020, rakyat Indonesia mengalami cukup banyak penderitaan yang sangat berkepanjangan dan tak kunjung berakhir yang dikarenakan oleh keberadaan suatu jenis penyakit atau pandemic baru yang dapat menular secara cepat. Penyakit tersebut disebut dengan Covid-19 yang kerap kali di takuti oleh banyak kalangan masyarakat Indonesia. Coronavirus ini memiliki 2 jenis, jenis yang dapat menyebabkan beberapa penyakit yang bisa mengakibatkan gejala berat seperti ketika wabah virus MERS dan virus SARS. COVID19 ini merupakan sejenis penyakit atau wabah baru yang bahkan tidak terdeteksi pada manusia sebelumnya. Bakteri penyebab penyakit COVID-19 ini diberi nama Sars-CoV-2[1][2].

Corona Virus Disease (COVID-19) adalah sebuah penyakit atau wabah yang bisa menular pada tubuh manusia serta dapat mengganggu sistem pernapasan yang akan mengakibatkan masalah pada sistem pernapasan manusia hingga dapat berujung pada kematian[3].

Social Distancing atau menjaga jarak sosial ini juga merupakan salah satu program yang memiliki tujuan guna pencegahan secara sedini mungkin untuk penularan penyakit COVID-19. Pada program ini Pemerintah menghimbau masyarakat agar melakukan langkah-langkah penerapan Social Distancing guna memperlambat bahkan memutus penyebaran virus COVID-19[4].

Dengan adanya kasus yang seperti demikian, peneliti memiliki ide atau pemikiran untuk menciptakan sebuah alat yang di mana nantinya alat tersebut akan dapat menjadi sebuah pengingat masyarakat tentang betapa pentingnya menjaga jarak. Alat tersebut disusun atas beberapa komponen seperti Minimum sistem Wemos D1 R1 yang bekerja sebagai controller nya, Sensor HC-SR04 berfungsi sebagai pendeteksi jarak, LCD I2C sebagai penampil display 
jarak yang terbaca, DF player berfungsi sebagai pengolah suara yang akan dikeluarkan oleh speaker, serta aplikasi blynk guna memantau monitoring jarak dan memberi peringatan ketika ada jarak yang berdekatan terdeteksi[5][6][7][8].

Prinsip kerja alat tersebut ialah ketika alat di hidupkan, sensor HC-SR04 akan mendeteksi jarak objek atau manusia yang berada di depannya. Jarak tersebut dapat dilihat melalui LCD 20x4 serta monitoring melalui IOT melalui Aplikasi Blynk yang ter-install pada smartphone[9][10].

\section{METODE}

Pada penelitian ini menggunakan metode pengambilan dan pengujian data yang dimana dari data yang telah diambil dan di uji akan digunakan untuk mengetahui perbandingan jarak yang di baca oleh sensor HC-SR04 serta keakurasian dari sensor tersebut serta melakukan monitoring secara jarak jauh dan pengiriman notifikasi secara jarak jauh via IoT melalui aplikasi blynk. Berikut ialah langkah-langkah pengujian yang dilakukan :

1. Langkah pertama yang dilakukan ialah melakukan perancangan alat terlebih dahulu.

2. Langkah kedua melakukan perancangan software yaitu berupa program menggunakan Arduino IDE.

3. Langkah ketiga membuat desain wadah untuk alat yang telah di rangkai.

4. Langkah keempat memasukan program pada minimum sistem Wemos D1 R1

5. Langkah kelima memasang alat yang telah dirangkai pada wadah yang telah dbuat

6. Melakukan percobaan serta pengambilan data dari akurasi pembacaan jarak sensor HC-SR04 serta melakukan perbandingan pada alat konvensional

7. Langkah terakhir melakukan pengujian pengiriman notifikasi dan monitoring jarak secara jarak jauh

Dari beberapa langkah-langkah percobaan dan pengujian tersebut akan didapatkan kesimpulan yang akan di uraikan pada bab 5.

\section{Hasil Dan Pembahasan}

\section{A. Pengujian minimum sistem wemos d1 r1}

Percobaan ini dilakukan guna mengetahui wemos d1 r1 dapat berfungsi sebagai alat komunikasi secara IoT yang di integrasikan pada smartphone. Indikator untuk mengetahui bahwa minimum sistem dapat menyala maka terdapat indikator lampu led berwarna biru.

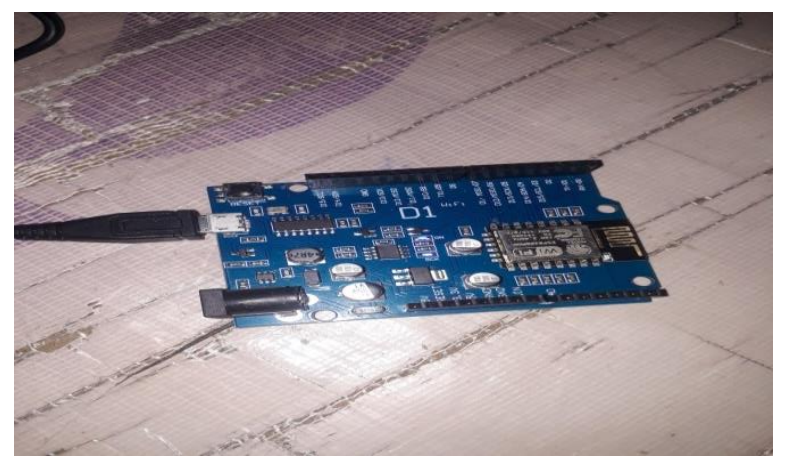

Gambar 1. Minimum Sistem Wemos D1 R1 Menyala

Pada Gambar 1 diatas merupakan percobaan minimum system Wemos D1 R1. Dapat dilihat lampu led pada Wemos D1 R1 menyala berwarna biru yang menandakan bahwa alat tersebut nyala dan dapat berfungsi. 


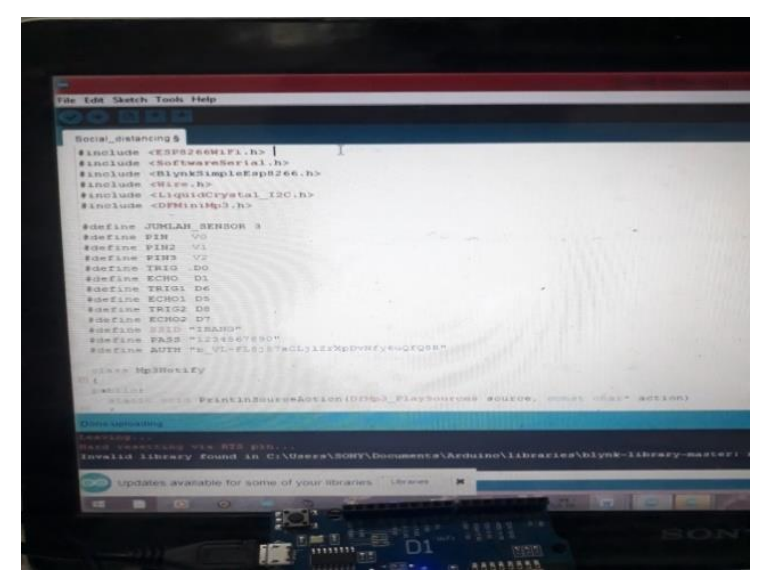

Gambar 2. upload program berhasil

Pada Gambar 2 Di atas merupakan uji coba peng-upload-an program pada Wemos D1 R1. Pada percobaan yang dilakukan hasilnya ialah program dapat di upload sehingga minimum sistem dapat menjalankan sensor, LCD, dan DF player.

\section{B. Pengujian df player}

Pada pengujian ini dilakukan guna memastikan DF player dapat berfungsi dan dapat memutar suara. Pengujian ini dilakukan dengan cara merangkai DF player sebagai pemutar suara, HC-SR04 sebagai input dan Speaker sebagai output pada Wemos D1 R1. Pada pengujian kali ini, ketika DF player berbunyi akan di tunjukkan dengan indikator output digital berupa angka 1, Jika DF player tidak berbunyi maka ditunjukkan dengan indikator angka 0.

Tabel 1. Data Hasil Pengujian DF Player

\begin{tabular}{ccc}
\hline No. & $\begin{array}{c}\text { Jarak Yang } \\
\text { Terdeteksi }(\mathrm{Cm})\end{array}$ & Output DF Player \\
\hline 1. & $9 \mathrm{Cm}$ & 0 \\
2. & $5 \mathrm{Cm}$ & 1 \\
3. & $22 \mathrm{Cm}$ & 0 \\
4. & $26 \mathrm{Cm}$ & 0 \\
5, & $7 \mathrm{Cm}$ & 1 \\
6. & $13 \mathrm{Cm}$ & 0 \\
7. & $6 \mathrm{Cm}$ & 1 \\
8. & $23 \mathrm{Cm}$ & 0 \\
9. & $8 \mathrm{Cm}$ & 1 \\
10. & $3 \mathrm{Cm}$ & 1 \\
\hline
\end{tabular}

Dapat kita amati Tabel 1 diatas, bahwa ketika sensor HC-SR04 sebagai inputan mendeteksi sebuah objek yang berjarak di bawah $8 \mathrm{~cm}$ ( 1 meter jarak nyata) maka DF player akan memutar suara dan speaker sebagai output akan mengeluarkan suara atau berbunyi.

\section{Pengujian pembacaan jarak sensor hc-sr04 pada lcd}

Pada pengujian ini dilakukan guna mengetahui pembacaan sensor HC-SR04 yang tertera pada LCD dan pengujian keakuratan sensor, serta melakukan perbandingan dengan hasil ukur dengan menggunakan alat konvensional meteran atau penggaris. 
Procedia of Engineering and Life Science Vol. 1. No. 2 Juni 2021

Seminar Nasional \& Call Paper Fakultas Sains dan Teknologi (SENASAINS 2nd)

Universitas Muhammadiyah Sidoarjo

Tabel 2. Pengujian Pembacaan Jarak Sensor HC-SR04 pada LCD

\begin{tabular}{|c|c|c|c|c|c|c|c|c|c|c|}
\hline \multirow[t]{2}{*}{ No. } & \multirow[t]{2}{*}{$\begin{array}{c}\text { Percobaan } \\
\text { pada }\end{array}$} & \multirow{2}{*}{$\begin{array}{l}\text { Percobaan } \\
\text { pada } \\
\text { penggaris } \\
\text { (cm) }\end{array}$} & \multicolumn{5}{|c|}{$\begin{array}{l}\text { Hasil pembacaan jarak yang di } \\
\text { tampilkan pada LCD }(\mathrm{cm})\end{array}$} & \multirow[t]{2}{*}{ Rata - Rata } & \multirow[t]{2}{*}{$\begin{array}{l}\text { Standar } \\
\text { deviasi }\end{array}$} & \multirow[t]{2}{*}{ Akurasi } \\
\hline & & & 1 & 2 & 3 & 4 & 5 & & & \\
\hline 1 & Sensor 1 & $10 \mathrm{~cm}$ & $10 \mathrm{~cm}$ & $10 \mathrm{~cm}$ & $10 \mathrm{~cm}$ & $10 \mathrm{~cm}$ & $10 \mathrm{~cm}$ & 10 & 0 & $100 \%$ \\
\hline
\end{tabular}

Pada Tabel 2 diatas terdapat hasil pengujian yang menjelaskan bahwa sensor 1 HC-SR04 yang di tampilkan pada LCD memiliki rata-rata pembacaan jarak yang stabil, serta keakuratan pembacaan jarak oleh sensor HC-SR04 yang sangat akurat hingga menyentuh angka $100 \%$. Sensor 1 juga memiliki nilai standard deviasi sebesar $0 \mathrm{~cm}$ yang menandakan tidak adanya selisih pembacaan sensor dengan alat pembanding yang berupa penggaris.

\section{Pengujian pembacaan jarak sensor hc-sr04 pada aplikasi blynk}

Pada pengujian ini dilakukan guna mengetahui pembacaan sensor HC-SR04 yang dikirimkan pada aplikasi blynk pada smarthphone dan pengujian keakuratan sensor, serta melakukan perbandingan dengan hasil ukur dengan menggunakan alat konvensional meteran atau penggaris.

Tabel 3. Pengujian Pembacaan Jarak Sensor HC-SR04 pada Blynk

\begin{tabular}{|c|c|c|c|c|c|c|c|c|c|c|}
\hline \multirow[t]{2}{*}{ No. } & \multirow[t]{2}{*}{$\begin{array}{c}\text { Percobaan } \\
\text { pada }\end{array}$} & \multirow{2}{*}{$\begin{array}{c}\text { Percobaan } \\
\text { pada } \\
\text { penggaris } \\
(\mathrm{cm})\end{array}$} & \multicolumn{5}{|c|}{$\begin{array}{c}\text { Hasil pembacaan jarak yang di } \\
\text { tampilkan pada blynk }(\mathrm{cm})\end{array}$} & \multirow[t]{2}{*}{ Rata - Rata } & \multirow[t]{2}{*}{$\begin{array}{l}\text { Standar } \\
\text { deviasi }\end{array}$} & \multirow[t]{2}{*}{ Akurasi } \\
\hline & & & 1 & 2 & 3 & 4 & 5 & & & \\
\hline 1 & Sensor 1 & $7 \mathrm{~cm}$ & $7 \mathrm{~cm}$ & $7 \mathrm{~cm}$ & $7 \mathrm{~cm}$ & $7 \mathrm{~cm}$ & $7 \mathrm{~cm}$ & 7 & 0 & $100 \%$ \\
\hline 2 & Sensor 2 & $8 \mathrm{~cm}$ & $8 \mathrm{~cm}$ & $8 \mathrm{~cm}$ & $8 \mathrm{~cm}$ & $8 \mathrm{~cm}$ & $8 \mathrm{~cm}$ & 8 & 0 & $-100 \%$ \\
\hline 3 & Sensor 3 & $9 \mathrm{~cm}$ & $9 \mathrm{~cm}$ & $9 \mathrm{~cm}$ & $9 \mathrm{~cm}$ & $9 \mathrm{~cm}$ & $9 \mathrm{~cm}$ & 9 & 0 & $100 \%$ \\
\hline
\end{tabular}

Pada pengujian Tabel 3 terdapat hasil dari pengujian 3 sensor yang memiliki tingkat pembacaan jarak sangat baik, yang dimana sensor 1 memiliki rata-rata tingkat pembacaan 7 dengan tingkat akurasi $100 \%$ serta standard deviasi $0 \mathrm{~cm}$ yang tidak ada selisih pembacaan, lalu sensor 2 memiliki rata-rata pembacaan 8 dengan tingkat akurasi $100 \%$ serta standart deviasi $0 \mathrm{~cm}$, dan yang terakhir sensor 3 memiliki rata -rata tingkat pembacaan 9 dengan tingkat akurasi $100 \%$ serta standar deviasi $0 \mathrm{~cm}$ yang menandakan tidak ada selisih pembacaan dengan alat standard berupa penggaris.

E. Pengujian monitoring dan notifikasi jarak jauh pada aplikasi blynk

Pada pengujian ini merupakan pengujian pemonitoringan jarak serta pengiriman notifikasi melalui aplikasi blink yang telah dikoneksikan dengan internet oleh minimum sistem Wemos D1 R1.

Tabel 4. Pengujian Monitoring Dan Notifikasi Jarak Jauh pada Aplikasi Blynk

\begin{tabular}{|c|c|c|c|c|c|c|c|}
\hline \multirow{2}{*}{ No. } & \multirow{2}{*}{ Daerah } & \multicolumn{3}{|c|}{$\begin{array}{l}\text { Jarak yang dibaca pada } \\
\text { aplikasi blynk }\end{array}$} & \multirow{2}{*}{$\begin{array}{c}\text { Device } \\
\text { (Smartphone) }\end{array}$} & \multirow[t]{2}{*}{ Provider } & \multirow{2}{*}{$\begin{array}{l}\text { Notifikasi } \\
\text { Blynk }\end{array}$} \\
\hline & & Sensor 1 & Sensor 2 & Sensor 3 & & & \\
\hline 1 & $\begin{array}{c}\text { Perumahan Buana Indah } \\
\text { Blok B-11, Ds. } \\
\text { Mulyamekar, Kec. } \\
\text { Babakancikao, }\end{array}$ & $5 \mathrm{~cm}$ & $14 \mathrm{~cm}$ & $12 \mathrm{~cm}$ & $\begin{array}{c}\text { Samsung } \\
\text { Galaxy A20s }\end{array}$ & XL & 1 \\
\hline
\end{tabular}


Procedia of Engineering and Life Science Vol. 1. No. 2 Juni 2021

Seminar Nasional \& Call Paper Fakultas Sains dan Teknologi (SENASAINS 2nd)

Universitas Muhammadiyah Sidoarjo

\begin{tabular}{|c|c|c|c|c|c|c|c|}
\hline & $\begin{array}{c}\text { Kab.Purwakarta, Jawa } \\
\text { Barat. }\end{array}$ & & & & & & \\
\hline 2 & $\begin{array}{c}\text { Desa Bulukandang, Kec. } \\
\text { Prigen, Kab. Pasuruan, } \\
\text { Jawa Timur. }\end{array}$ & $5 \mathrm{~cm}$ & $17 \mathrm{~cm}$ & $16 \mathrm{~cm}$ & Redmi Note 9 & Telkomsel & 1 \\
\hline 3 & $\begin{array}{c}\text { Perumahan Puspa } \\
\text { Garden BE-5,Ds. } \\
\text { Kedungkendo, Kec. } \\
\text { Candi, Kab. Sidoarjo, } \\
\text { Jawa Timur. }\end{array}$ & $5 \mathrm{~cm}$ & $17 \mathrm{~cm}$ & $16 \mathrm{~cm}$ & $\begin{array}{l}\text { Asus Zenfone } \\
\text { Maxpro M1 }\end{array}$ & By.u & 1 \\
\hline 4 & $\begin{array}{l}\text { Gg. Cempaka, Magasari, } \\
\text { Kutorejo, Kec.Pandaan, } \\
\text { Kab. Pasuruan, Jaws } \\
\text { Timur. }\end{array}$ & $7 \mathrm{~cm}$ & $9 \mathrm{~cm}$ & $12 \mathrm{~cm}$ & Redmi Note 7 & Telkomsel & 1 \\
\hline 5 & $\begin{array}{l}\text { Jl. Pandugo Baru IX } \\
\text { No.37, Penjaringan Sari, } \\
\text { Kec. Rungkut, Kota } \\
\text { Surabaya, Jawa Timur. }\end{array}$ & $11 \mathrm{~cm}$ & $14 \mathrm{~cm}$ & $6 \mathrm{~cm}$ & $\begin{array}{l}\text { Xiaomi redmi } \\
4 \mathrm{X}\end{array}$ & 3 (Tri) & 1 \\
\hline
\end{tabular}

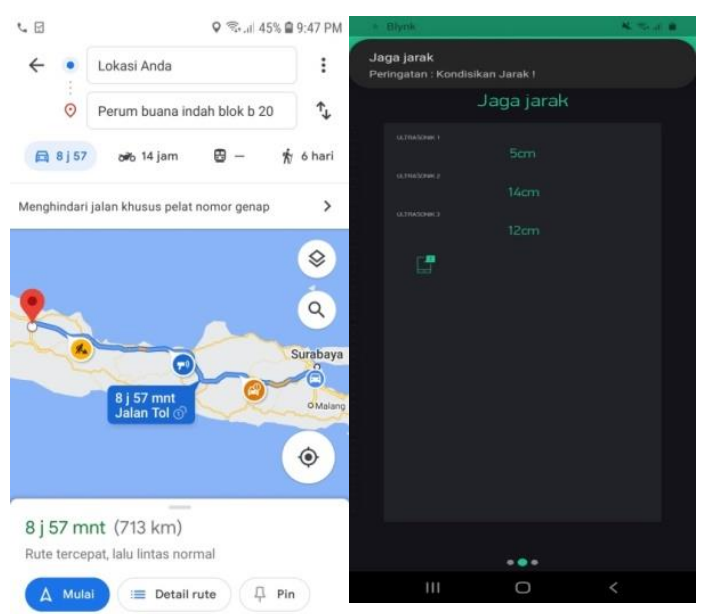

Gambar 3. Percobaan Blynk pada Daerah Purwakarta

Pada Gambar 3. merupakan percobaan blynk yang dapat diakses dari kabupaten purwakarta, jawa barat. Pada percobaan tersebut aplikasi blynk dapat memonitoring dan memberi notifikasi ketika mendeteksi jarak kurang dari 8 cm ( 1 meter jarak nyata ) secara langsung dari jarak yang cukup jauh.

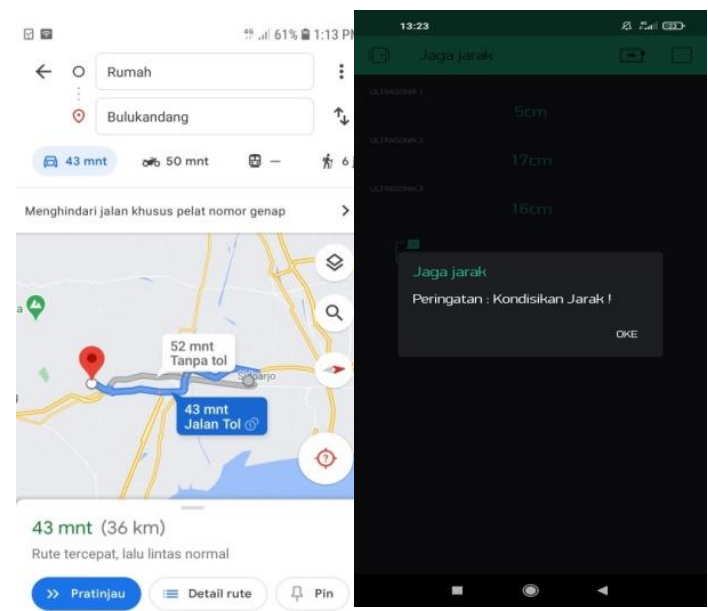

Gambar 4. Percobaan Blynk pada Daerah Prigen 
Pada Gambar 4. ini adalah percobaan monitoring jarak dengan blynk yang dapat diakses dari desa bulukandang, kecamatan prigen, kab pasuruan, jawa timur. Pada percobaan tersebut aplikasi blynk dapat memonitoring secara langsung dari jarak jauh dan notifikasi berhasil masuk ketika sensor mendekteksi jarak dibawah $8 \mathrm{~cm}(1 \mathrm{~meter} \mathrm{jarak}$ nyata).

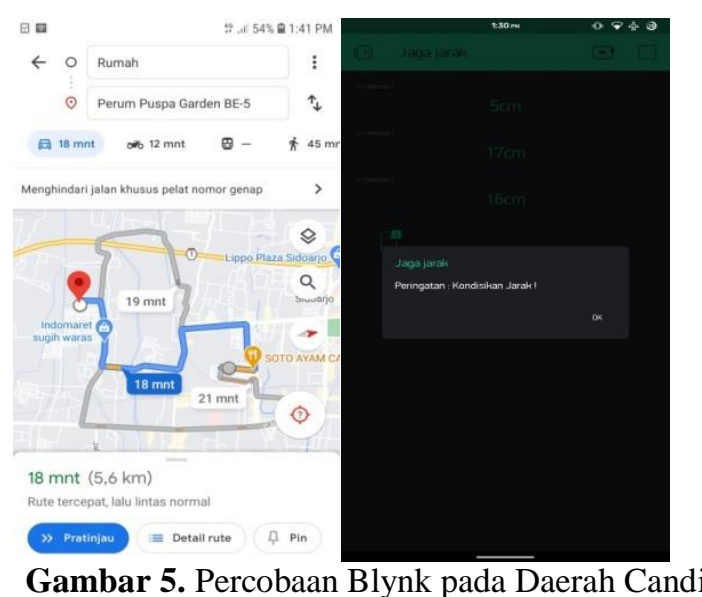

Pada Gambar 5 merupakan percobaan blynk yang diakses dari daerah kecamatan candi, kabupaten sidoarjo, jawa timur. Pada percobaan tersebut aplikasi blynk dapat dengan smartphone Asus Zenfone Maxpro M1 dan provider By.u guna memonitoring secara langsung dari jarak yang lumayan jauh jauh dan notifikasi berhasil masuk ketika sensor mendekteksi jarak dibawah $8 \mathrm{~cm}$ (1 meter jarak nyata).

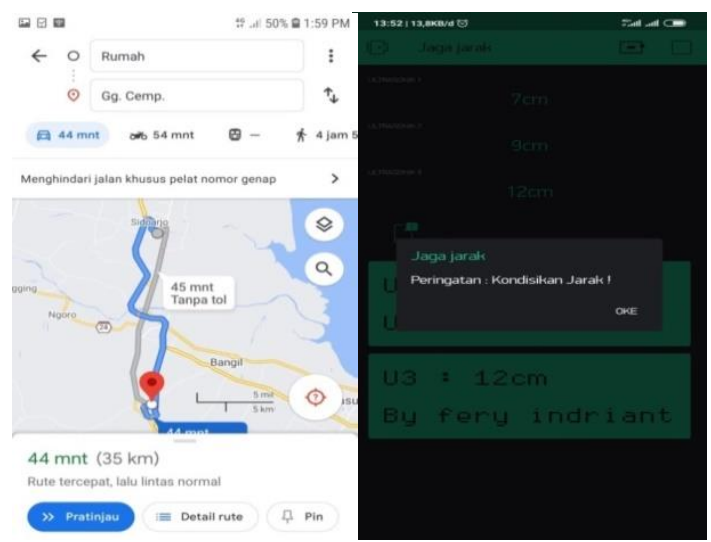

Gambar 6. Percobaan Blynk pada Daerah Pandaan

Pada Gambar 6. merupakan percobaan blynk yang diakses dari daerah kecamatan pandaan, kabupaten pasuruan, jawa timur. Pada percobaan tersebut aplikasi blynk dapat di akses dengan smartphone Redmi note 7 dan provider telkomsel guna memonitoring dan menerima notifikasi jauh dan notifikasi berhasil masuk ketika sensor mendekteksi jarak dibawah $8 \mathrm{~cm}$ (1 meter jarak nyata) dari jarak yang cukup jauh.

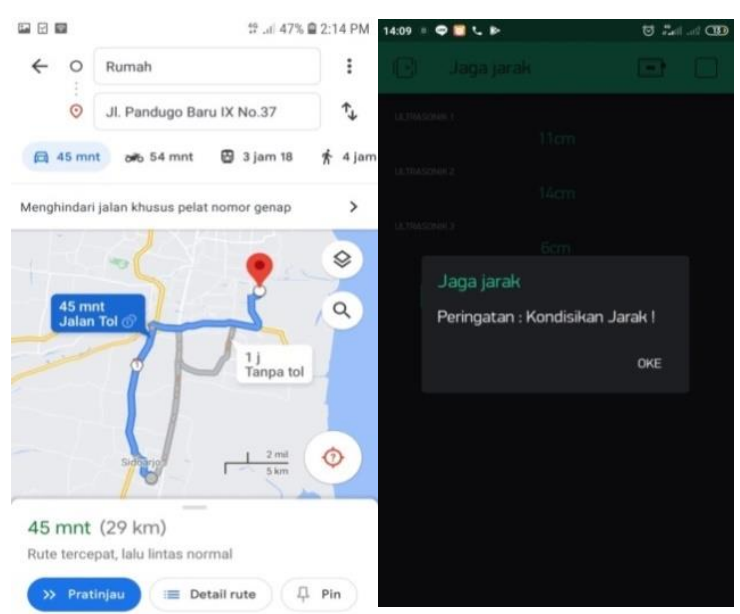

Gambar 7. Percobaan Blynk pada Daerah Rungkut 
Pada Gambar 7 merupakan percobaan blynk yang di akses dari kecamatan rungkut, kota surabaya, jawa timur. Pada percobaan tersebut aplikasi blynk dapat berfungsi dengan baik dan dapat diakses dengan smartphone Xiaomi Redmi 4X dan provider 3 (Tri) guna memonitoring secara langsung dari jarak yang cukup jauh dan jauh dan notifikasi berhasil masuk ketika sensor mendekteksi jarak dibawah $8 \mathrm{~cm}$ (1 meter jarak nyata).

\section{Pengujian Secara Keseluruhan}

Pada percobaan ini dilakukanlah pengujian hardware secara keseluruhan. Mulai dari Minimum system Wemos D1 R1, pengamatan pembacaan sensor HC-SR04 yang ditampilkan LCD, Pemutaran suara oleh DF Player, Dan output atau keluaran berupa bunyi yang di hasilkan speaker.

Tabel 5. Pengujian Secara Keseluruhan

\begin{tabular}{ccccccc}
\hline No & $\begin{array}{c}\text { SPenggaris } \\
(\mathrm{cm})\end{array}$ & $\begin{array}{c}\text { SLCD } \\
(\mathrm{cm})\end{array}$ & SBlynk $(\mathrm{cm})$ & $\begin{array}{c}\text { Pesan Peringatan } \\
\text { pada LCD }\end{array}$ & $\begin{array}{c}\text { Bunyi } \\
\text { DF Player }\end{array}$ & $\begin{array}{c}\text { Notifikasi } \\
\text { Pada Blynk }\end{array}$ \\
\hline 1 & $6 \mathrm{~cm}$ & $6 \mathrm{~cm}$ & $6 \mathrm{~cm}$ & Jaga Jarak Anda & 1 & 1 \\
2 & $10 \mathrm{~cm}$ & $10 \mathrm{~cm}$ & $10 \mathrm{~cm}$ & Waspada & 0 & 0 \\
3 & $3 \mathrm{~cm}$ & $3 \mathrm{~cm}$ & $3 \mathrm{~cm}$ & Jaga Jarak Anda & 1 & 0 \\
4 & $14 \mathrm{~cm}$ & $14 \mathrm{~cm}$ & $14 \mathrm{~cm}$ & Waspada & 0 & 0 \\
5 & $32 \mathrm{~cm}$ & $32 \mathrm{~cm}$ & $32 \mathrm{~cm}$ & Aman & 0 & 0 \\
\hline
\end{tabular}

Pada Tabel 5 merupakan data hasil pengujian alat secara keseluruhan. Pada pengujian ini peneliti menguji alat keseluruhan mulai dari pembacaan jarak, pesan peringatan pada LCD, DF Player, hingga pengiriman notifikasi pada aplikasi blynk yang telah di install pada smartphone.

\section{KESIMPULAN}

Dari beberapa pengujian yang telah dilakukan, terdapat beberapa data pengujian yang telah diambil. maka, dapat di ambil kesimpulan sebagai berikut :

Pada dasarnya alat ini memiliki cara kerja seperti, Sensor 1 yang di gunakan pada loket akan mendeteksi jarak, sehingga ketika ada objek yang mendekat hingga di bawah $8 \mathrm{~cm}$ (1 meter jarak nyata) maka DF player akan berbunyi “Jaga jarak anda " serta mengirim notifikasi pada aplikasi blynk dan pesan peringatan yang tertera pada LCD yang awal mula berupa "aman" akan berubah menjadi "Jaga jarak anda!". Sensor 2 dan 3, digunakan untuk mendeteksi objek yang berdiri didepannya, sehingga ketika ada objek atau manusia yang berhenti didepan sensor 2 dan 3 maka sensor 2 dan 3 akan mengirim notifikasi pada aplikasi blynk serta DF player akan berbunyi. Tingkat keakuratan pembacaan jarak dari ketiga sensor cukup akurat hingga menyentuh angka $100 \%$, serta pengiriman notifikasi dan monitoring jarak jauh dapat berjalan dengan lancar.

\section{REFERENSI}

[1] D. Tuwu, "Kebijakan Pemerintah Dalam Penanganan Pandemi Covid-19," J. Publicuho, vol. 3, no. 2, p. 267, 2020

[2] T. N. I. Zulva, "Covid-19 Dan Kecenderungan Psikosomatis," J. Chem. Inf. Model., pp. 1-4, 2020

[3] Jamaaluddin; Izza Anshory; Shazana, "DISEMINASI DISINFEKTAN COVID-19 PEMBANGKIT LISTRIK TENAGA SURYA PADA MASJID BAITUL MUTTAQIIN PUCU'AN,” vol. 1, no. 2, pp. 8-11, 2020.

[4] N. A. Pratama and D. Hidayat, "Pengetahuan dan Perilaku Masyarakat Memaknai Social Distancing," J. Digit. Media Relatsh., vol. 2, no. 1 , pp. 1-10, 2020.

[5] R. Bangun, A. Penyemprot, and P. Otomatis, "Design of Automatic Pesticide Sprayers on Internet-Based Chilli Plants Rancang Bangun Alat Penyemprot Pestisida Otomatis Pada Tanaman Cabai Berbasis ( Internet of Things )," vol. 4, no. 2, pp. 89-98, 2020.

[6] B. Arsada, "APLIKASI SENSOR ULTRASONIK UNTUK DETEKSI POSISI JARAK PADA RUANG MENGGUNAKAN ARDUINO UNO," J. Tek. Elektro, 2017.

[7] R. P. Pratama, A. Mas'ud, C. Niswatin, and A. A. Rafiq, “Implementasi DFPlayer untuk Al-Qur'an Digital berbasis Mikrokontroler ESP32," INVOTEK J. Inov. Vokasional dan Teknol., 2020.

[8] Rifansyah, "Datasheet I2C 1602 Serial LCD Module," Eprint.Polsri.Ac.Id, 2017.

[9] S. Syahrorini and D. Hadidjaja, “Aplikasi Alat Ukur Partikulat Dan Suhu Berbasis Iot,” Dinamik, vol. 25, no. 1, pp. 1-9, 2020.

[10] A. M. Wisaksono, Purwanti, Novia, "Design of Monitoring and Control of Energy Use in Multi-storey Buildings based on IoT," JEEE-U (Journal Electr. Electron. Eng. UMSIDA, vol. 4, no. 2, pp. 128-135, 2020. 